\title{
The teaching of physical education in colleges and universities based on the idea of ecological civilization.
}

Fu Wei*

Department of PE Teaching and Research, South China Agricultural University, GuangZhou, Guangdong, PR China

\begin{abstract}
With the continuous development of economy, science, technology, and education, people pay more and more attention to the ecological balance. In all aspects of social development, people emphasize ecological development. And college education is an important part of the cultivation of social talents. Physical education teaching has also been concerned. In this paper, the status quo of physical education teaching in colleges and universities was briefly summarized. At the same time, the current situation of physical education teaching in colleges and universities in China was analysed by using SPSS statistical software. Based on the concept of ecological civilization under the college physical education teaching at the present stage of the problem, the corresponding solution was put forward.
\end{abstract}

Keywords: Ecological civilization, College education, Questionnaire investigation.

Accepted on June 2, 2017

\section{Introduction}

Physical education is one of the main components of higher education, it plays an important role in the cultivation of comprehensive talents and the development of physical education, therefore, it is necessary to research and analyse the problems that need to be solved and perfected. After the eighteen generation of the party's report, ecological civilization has become the direction of social development; the society has begun to change from industrial civilization to ecological civilization. Under the social construction of this idea, colleges and universities have been regarded as the training bases of social successors. Therefore, this paper analyses the current situation of physical education in colleges and universities in China.

\section{State of the Art}

In the study abroad, there are many sports teaching mode. For example, in 70's, the teaching mode of physical education in Colleges and universities in Germany emphasized how to transfer the knowledge of teachers to students [1]. In recent years, through the continuous study and reform of college physical education and teaching scholars, physical education teaching model becomes the model that the teachers teach content and the students carry out the self-study, and then the teachers evaluate the student's self-study situation, and finally the teachers and students learn new knowledge together. Foreign scholars focus on the study of physical education teaching model, for the ecological civilization theory of physical education teaching research is less.
In our country, the ecology began to be introduced into education in the 1970's. In the 1980's, China began to carry out ecological research under the theory of ecology, some scholars through the ecology and sports research methods and theories to organize the integration, they began to analyse the principles of ecology to study sports, so as to grasp the trend of sports development [2]. Up to now, with the deteriorating natural environment, the sustainable development of sports has also been paid much attention by government and academic researchers. Based on this, it is necessary to study the teaching mode of physical education in colleges and universities under the concept of ecological civilization.

\section{Methodology}

This article through the questionnaire survey form to study the current situation of physical education in colleges and universities by introducing the theory of ecological civilization into the teaching research of physical education in colleges and universities. According to the contents of this paper, we selected related issues to conduct a survey of college physical education teaching mode of 30 colleges and universities nationwide by telephone, mail, face-to-face. The results of the survey are shown in Table 1.

Table 1. Investigation on the types of physical education teaching mode in colleges and universities in China.

\begin{tabular}{lll}
\hline Schema type & School & Percentage \\
\hline Three type & 6 & $20 \%$ \\
\hline side by side & 5 & $16.67 \%$ \\
\hline
\end{tabular}




\begin{tabular}{lll}
\hline Integrated type & 2 & $6.67 \%$ \\
\hline Three segment type & 8 & $26.67 \%$ \\
\hline Elective class & 7 & $23.33 \%$ \\
\hline Club type & 2 & $6.67 \%$ \\
\hline
\end{tabular}

For the results of the survey, SPSS statistical software is used to sort out the six aspects of college PE teaching from the central idea, teaching goal, content, method, organization form and evaluation. From the results of the questionnaire survey, the central idea of physical education in colleges and universities is still the dominant position of sports skill education. At present, the goal of physical education in China is based on the central idea of skills education. The concept of ecological civilization to promote the full development of student education ideas have not been fully implemented, and has not established a healthy concept of physical education. The content of physical education teaching in China is basketball, football and volleyball, new sports events such as tennis, outdoor expansion in colleges and universities, the content of physical education teaching in colleges and universities in China has not been adjusted in time according to the direction of social development and the needs of students. The teaching methods of physical education in China are shown in Figure 1.

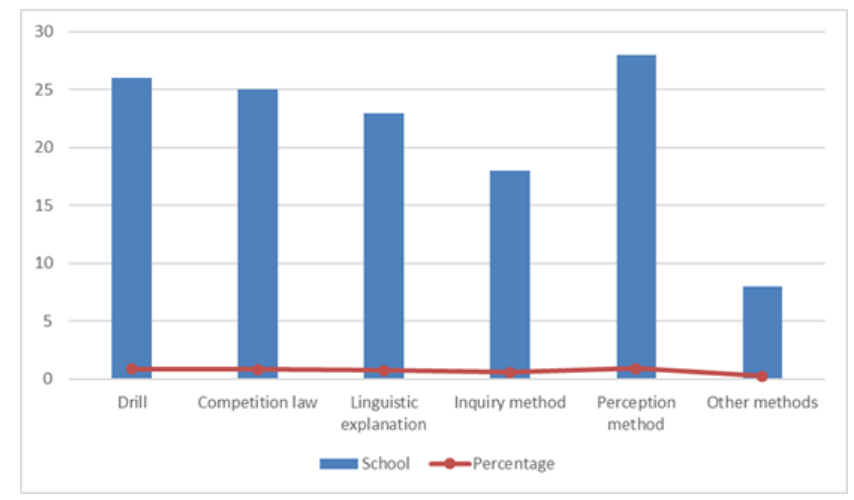

Figure 1. Investigation on teaching methods of physical education in colleges and universities in China.

From the above table, it can be seen that at present, the teaching methods of physical education teachers in colleges and universities in China are still relatively primitive methods of perception and practice. China's college sports group teaching organizations have various forms, each university according to their actual situation to choose, but they still take the technical examination and the usual results as a basis for the evaluation of student teaching. The application of humanized evaluation method which is based on the students' progress and the score of extracurricular physical training is few in physical education colleges.

\section{Result Analysis and Discussion}

From the results of the questionnaire, it can be seen that in view of the problems existing in the teaching of physical education in China, the central idea of physical education and teaching in colleges and universities in our country should attach importance to the renewal of teaching idea and make the guiding ideology of lifelong sports consciousness as the central idea of college physical education teaching, this is also the long-term goal of the development of college physical education. In order to cultivate students' individual sports skills and develop individual sports learning ability, the teaching content of sports education should be enriched; according to the characteristics of the times, the new projects such as tennis, climbing, as well as the national sports related can also be introduced, such as martial art, qigong, etc.. We cannot only pay attention to the students of sports skills to learn, but also should attach importance to sports theory education, so that students can understand sports knowledge and related skills more comprehensively, and create a good sports atmosphere and the human environment. Through various forms of ecological sports activities, more students and teachers participate in sports activities. The teaching methods should be modernized, and should be trained according to the students' personal characteristics. In the aspect of teaching evaluation, the subjective initiative of the evaluation object should be brought into play, and the students' individual sports ability should be included in the evaluation system.

\section{Conclusions}

The concept of ecological civilization is the trend of social development. With the increasing economic environment, people pay more and more attention to the ecological development of the natural environment; correspondingly, college education is an important part of the social development of talent, and physical education in colleges and universities is an important part of it, which has an important position in the development of higher education, therefore, it is necessary to study the teaching of physical education in colleges and universities under the concept of ecological civilization. Based on this, in this paper, through a brief summary of the current situation of physical education teaching in colleges and universities, as well as the questionnaire survey and related statistical software, the results were analysed, the present situation of physical education teaching in our country was drawn. At the same time, the corresponding solutions were put forward to provide some related theories for the teaching of college physical education under the concept of ecological civilization.

\section{References}

1. Torner G, Potari D, Zachariades T. Calculus in European classrooms: curriculum and teaching in different educational and cultural contexts. ZDM 2014; 46: 549-560.

2. La Charite K. Re-visioning agriculture in higher education: the role of campus agriculture initiatives in sustainability education. Agr Human Values 2016; 33: 521-535. 
The teaching of physical education in colleges and universities based on the idea of ecological civilization

\section{*Correspondence to}

Fu Wei

Department of PE Teaching and Research

South China Agricultural University

PR China 